\title{
SOURCES OF INCIDENTAL EVENTS IN COLLECTIVE WATER SUPPLY SYSTEM
}

\section{ŹRÓDLA ZDARZEŃ INCYDENTALNYCH W SYSTEMIE ZBIOROWEGO ZAOPATRZENIA W WODE}

\author{
Dawid Szpak, Barbara Tchórzewska - Cieślak \\ Politechnika Rzeszowska \\ e-mail:dsz@prz.edu.pl,cbarbara@prz.edu.pl
}

\begin{abstract}
The publication presents the main types of incidental events in collective water supply system. The special attention was addressed to the incidental events associated with a decrease in water quality, posing a threat to the health and life of inhabitants. The security method against incidental contamination in the water source was described.
\end{abstract}

Keywords: incidental events, collective water supply system

Streszczenie: $W$ pracy scharakteryzowano główne rodzaje zdarzeń incydentalnych $w$ systemie zbiorowego zaopatrzenia $w$ wodę. Szczególna uwage zwrócono na zdarzenia incydentalne związane $z$ obniżeniem jakości wody, stanowiace zagrożenie dla zdrowia i życia mieszkańców. Przedstawiono sposób zabezpieczeń mieszkańców przed incydentalnym zanieczyszczeniem źródła wody.

Stowa kluczowe: zdarzenia incydentalne, system zbiorowego zaopatrzenia w wode 
Sources of incidental events in collective water supply system

Źródta zdarzeń incydentalnych $w$ systemie zbiorowego zaopatrzenia $w$ wodę

\section{Wstęp}

Przynależność systemu zbiorowego zaopatrzenia w wodę (SZZW) do infrastruktury krytycznej wymaga od przedsiębiorstw wodociągowych zapewnienia ciągłości funkcjonowania oraz szybkiego odtworzenia stanu sprawności w przypadku wystąpienia awarii. Wyróżnia się trzy grupy czynników stanowiących przyczynę zdarzeń niepożądanych w SZZW: czynniki techniczne, ludzkie oraz środowiskowe [9]. Przedsiębiorstwa wodociągowe są w większości przygotowane na radzenie sobie ze skutkami regularnie występujących, eksploatacyjnych awarii sieci wodociągowych. Znacznie większe niebezpieczeństwo niesie ze sobą wystąpienie zdarzenia incydentalnego.

Zdarzenie incydentalne w SZZW definiuje się jako zdarzenie, którego zajście stanowi poważne zagrożenie dla życia i zdrowia odbiorców wody, powodujące znaczne szkody dla przedsiębiorstwa wodociągowego i którego wystąpienie dla zarządzającego SZZW jest trudne do przewidzenia. Prawdopodobieństwo zajścia takiego zdarzenia, określane na podstawie metod probabilistycznych jest małe, jednak straty które może ono spowodować wymagają od przedsiębiorstw wodociągowych wprowadzenia szczelnego systemu zabezpieczeń przed ich negatywnymi skutkami [9]. O zagrożeniu zdrowia i życia mieszkańców można mówić przede wszystkim wtedy, gdy woda dostarczona do odbiorców nie spełnia wymagań jakościowych zawartych w Rozporządzeniu [13]. W przypadku braku dostawy wody, zdrowie i życie odbiorców wody nie jest bezpośrednio zagrożone, występuje jednak zagrożenie sanitarne. Poniżej przedstawiono główne rodzaje zdarzeń incydentalnych mogących wystąpić w SZZW [8]:

- zanieczyszczenie w przekroju rzeki zlokalizowanym powyżej ujęcia, na wystąpienie którego proces uzdatniania wody nie jest przygotowany, spowodowane przez:

- zdarzenia o znamionach poważnej awarii oraz poważne awarie, np. zanieczyszczenie rzeki substancjami ropopochodnymi spowodowane katastrofą w ruchu lądowym,

- celowe działanie osób trzecich: działania wojenne, atak terrorystyczny lub cyberterrorystyczny, atak psychopaty lub akt wandalizmu,

- powódź,

- suszę,

- zanieczyszczenie wody w sieciowych zbiornikach wodociągowych,

- wtórne zanieczyszczenie wody w sieci wodociągowej,

- awaria głównych elementów stacji uzdatniania wody (SUW),

- awaria pomp w pompowni pierwszego oraz drugiego stopnia,

- globalny zanik energii elektrycznej,

- awaria głównych przewodów tranzytowych oraz magistralnych.

Głównym celem pracy jest charakterystyka zdarzeń incydentalnych w SZZW oraz przedstawienie możliwości zabezpieczeń przed incydentalnym skażeniem źródła wody. 


\section{Zdarzenia związane $\mathrm{z}$ incydentalnym zanieczyszczeniem źródła wody}

\section{Zdarzenia o znamionach poważnej awarii oraz poważne awarie}

Wg Ustawy [18], poważna awaria jest to zdarzenie powstałe w trakcie procesu przemysłowego, magazynowego lub transportu, którego skutkiem jest powstanie zagrożenia zdrowia lub życia ludzi spowodowane przez występowanie substancji niebezpiecznych. Poważna awaria stanowi zagrożenie dla SZZW wtedy, gdy dochodzi do zanieczyszczenia wód powierzchniowych lub podziemnych stanowiących źródło wody substancjami, których proces uzdatniania wody nie jest w stanie usunąć. W związku z tym, że spożycie skażonej wody może spowodować poważne skutki zdrowotne, zadaniem przedsiębiorstwa wodociągowego jest jak najlepsza ochrona odbiorców. Źródła zagrożeń ekologicznych zasobów wód [10]:

- źródła zlokalizowane, określone - związane z zakładami o dużym ryzyku wystąpienia awarii przemysłowej (ZDR) oraz zakładami o zwiększonym ryzyku wystąpienia awarii przemysłowej (ZZR),

- źródła niezlokalizowane, określone - związane $\mathrm{z}$ transportem substancji niebezpiecznych,

- źródła zlokalizowane, nieokreślone - związane z punktami przeładunku substancji niebezpiecznych,

- sieć kanalizacyjna - zdarzenia związane z wyciekiem ścieków sanitarnych do gruntu lub rzeki.

W tabeli 1 przedstawiono liczbę zdarzeń o znamionach poważnej awarii oraz poważnych awarii w latach 2009 - 2013, przeanalizowanych na podstawie danych Głównego Inspektoratu Ochrony Środowiska [22].

Tabela 1. Liczba zdarzeń o znamionach poważnej awarii oraz powaznych awarii w latach 2009 - 2013 [22]

\begin{tabular}{|l|c|c|c|c|c|}
\hline Rok & 2009 & 2010 & 2011 & 2012 & 2013 \\
\hline Liczba awarii & 143 & 114 & 83 & 91 & 84 \\
\hline
\end{tabular}

Zauważa się spadek liczby zdarzeń o znamionach poważnej awarii oraz poważnych awarii w latach 2009 - 2013. Poważne awarie, mogą być przyczyną nie tylko skażenia wody substancjami toksycznymi, ale także substancjami promieniotwórczymi. Kryterium radiologiczne, mimo znacznego wpływu na występowanie wielu chorób cywilizacyjnych, nie jest uwzględniane $\mathrm{w}$ ocenie przydatności wody do spożycia przez ludzi. Źródło promieniowania stanowią radionuklidy pochodzenia geologicznego i ze źródeł sztucznych oraz pochodzące $\mathrm{z}$ transmutacji stabilnych izotopów pod wpływem promieniowania kosmicznego [6]. 
Sources of incidental events in collective water supply system

Źródta zdarzeń incydentalnych $w$ systemie zbiorowego zaopatrzenia $w$ wodę

Dzialania wojenne, akt terrorystyczny oraz cyberterrorystyczny, atak psychopaty, akt wandalizmu

Według Ministerstwa Spraw Zagranicznych Polska nie jest głównym celem zainteresowania międzynarodowych organizacji terrorystycznych. Ze względu jednak na zaangażowanie Polski w wojskowe misje zagraniczne, takie jak misja pokojowa w Afganistanie czy misja stabilizacyjna w Iraku, istnieje pewne ryzyko ataku ugrupowań terrorystycznych lub ekstremistycznych na nasz kraj [23]. System zbiorowego zaopatrzenia $\mathrm{w}$ wodę wydaje się być potencjalnym celem ataku dla takich organizacji. Atak polegający na wprowadzeniu do wody surowej lub uzdatnionej trujących środków chemicznych bądź biologicznych jest bardzo groźny ze względu na to, że jego skutki mogą pojawić się dopiero po upływie kilku dni [12]. Dostępność i stosunkowo łatwa produkcja czynników szkodliwych powoduje, że terroryzm biologiczny i chemiczny może stanowić większe zagrożenie niż terroryzm nuklearny [20]. Nie każdy rodzaj broni chemicznej jest groźny dla użytkowników SZZW. Niektóre z gazów bojowych nie rozpuszczają się wodzie lub rozkładają, dlatego nie stanowią zagrożenia dla konsumentów wody.

Niepokój wywołuje rosnące napięcie na arenie międzynarodowej związane z sytuacją na Ukrainie oraz Bliskim Wschodzie. W związku z tymi wydarzeniami, jeszcze bardziej zasadne wydaje się być opracowanie efektywnego systemu wykrywania zagrożeń oraz planów reagowania kryzysowego, umożliwiających zabezpieczenie strategicznych punktów SZZW należącego do infrastruktury krytycznej [17] przed skażeniem substancjami trującymi. Ponadto rozważyć należy także możliwość fizycznego zniszczenia obiektu. Polska powinna być przygotowana na każdy możliwy wariant związany $\mathrm{z}$ rozwojem konfliktu na terenie naszego wschodniego sąsiada.

Przykładowe środki wykorzystywane jako broń chemiczna to: adamsyt, cyjanowodór, chlorocyjan, fosgen, difosgen, iperyt, luizyt, soman, sarin czy tabun. Czynniki zaliczane do broni biologicznej: bakterie, wirusy, grzyby, toksyny bakteryjne i inne. Substancje trujące mogą być wprowadzone do SZZW poprzez ujęcie wody lub zbiorniki wodociągowe. W przypadku zatrucia wody $\mathrm{w}$ rzece powyżej ujęcia wody substancjami trującymi efektywność ich działania maleje na skutek rozcieńczenia wodą rzeczną [12]. Groźniejsze wydaje się być zatrucie wody znajdującej się $\mathrm{w}$ zbiornikach sieciowych. Woda ta trafia bezpośrednio do sieci i jej zatrucie stanowi poważne zagrożenie dla zdrowia i życia mieszkańców. Z tego też powodu zbiornik wodociągowy powinien być zabezpieczony przed przestępczym działaniem osób trzecich poprzez ograniczenie do minimum liczby otworów zbiornika, zapewnienie stałego nadzoru lub niezawodnego systemu alarmowego, monitoring najważniejszych miejsc zbiornika oraz zastosowanie sygnalizatora ruchu [1].

Coraz większe zagrożenie dla bezpieczeństwa SZZW stanowi cyberterroryzm, czyli akt terroru wykorzystujący zdobycze technologii informacyjnej. System zbiorowego zaopatrzenia $\mathrm{w}$ wodę ze względu na to, że jego zniszczenie stanowi zagrożenie dla życia i zdrowia ludzi, wchodzi w skład cyberprzestrzeni Rzeczpospolitej Polskiej, za ochronę której odpowiedzialny jest Prezes Rady Ministrów [21]. Cyberterroryzm może być przyczyną poważnych zakłóceń w pracy zdalnie sterowanych i monitorowanych podsystemów SZZW [15]. 


\section{Powódź}

W strefie klimatycznej umiarkowanej do której zaliczany jest klimat Polski powodzie występują przede wszystkim w okresie wiosennym. Skutkiem powodzi jest pogorszenie się parametrów fizycznych oraz chemicznych jakości wody takich jak związki azotu i fosforu, zawiesina ogólna, barwa, tlen rozpuszczony, temperatura, ChZT oraz liczba bakterii coli. Powódź powoduje także wzrost stężenia substancji biogennych. Przyczyną tych zmian jest wymywanie drobnoustrojów chorobotwórczych $\mathrm{z}$ systemów kanalizacyjnych, szamb, śmietników, gnojowników, cmentarzy czy systemów unieszkodliwiania odpadów. Stacja uzdatniania wody często nie jest przygotowana na uzdatnienie skażonej wody, co prowadzi do deficytu wody pitnej na obszarze dotkniętym powodzią. $\mathrm{Z}$ jeszcze trudniejszą sytuacją mamy do czynienia w przypadku zalania SUW-u, co związane jest $z$ koniecznością ewakuacji operatorów i wstrzymania procesu uzdatniania. Ponadto powódź jako zdarzenie o charakterze ekstremalnym często powoduje występowanie skrajnych zachowań u mieszkańców, co utrudnia prowadzenie akcji ratunkowej i zaopatrzenie ludzi w wodę butelkowaną lub $\mathrm{z}$ beczkowozów [2].

Intensywne opady oraz roztopy nie tylko są przyczyną powodzi ale także stanowią główne źródło nadmiernej, trudnej do usunięcia mętności wody rzecznej. Na zwiększenie mętności wpływają osady denne oraz zawiesiny transportowane z wysoką prędkością spowodowaną wysokim stanem wody. Szczególnie podatne na okresowe skoki mętności są rzeki górskie [4].

\section{Susza}

Występowanie suszy hydrologicznej znacznie zwiększa ryzyko deficytu wody zdatnej do picia na zagrożonym obszarze. Najbardziej narażeni na ryzyko braku dostawy wody są mieszkańcy terenów górskich, obszarów o bardzo intensywnym poborze wody oraz obszarów silnie odwodnionych [3]. Spadek poziomu wody w rzekach stanowiących źródło wody dla miasta powoduje także wzrost stężenia zanieczyszczeń w wodzie rzecznej, co może stanowić poważny problem dla eksploatatorów SUW. Dopływające do cieku rzecznego zanieczyszczenia nie są rozcieńczane $\mathrm{w}$ takim stopniu jak podczas normalnych stanów wód, co wymaga dostosowania technologii uzdatniania do zachodzących zmian.

\section{Wtórne zanieczyszczenie wody w sieci wodociągowej}

Główną przyczyną pojawienia się wtórnego zanieczyszczenia $\mathrm{w}$ sieci wodociągowej jest brak stabilności chemicznej lub biologicznej, niedostateczna zawartość dezynfekanta $\mathrm{w}$ wodzie oraz zmienne warunki hydrauliczne [14]. Wprowadzenie do podsystemu dystrybucji wody niestabilnej chemicznie lub biologicznie może być spowodowane awarią na SUW lub błędem operatora SUW. Niestabilna chemicznie woda charakteryzuje się korozyjnością lub skłonnością do wytrącania osadów. Ze względu na fakt, że znaczny procent starszych przewodów wodociągowych $\mathrm{w}$ Polsce wykonanych jest $\mathrm{z}$ żeliwa szarego i stali wtórne zanieczyszczenie wody $\mathrm{w}$ sieci wodociągowej objawia się brunatna barwą oraz zwiększoną mętnością. 
Sources of incidental events in collective water supply system

Źródła zdarzeń incydentalnych $w$ systemie zbiorowego zaopatrzenia $w$ wode

Stabilna biologicznie woda jest pozbawiona substancji pokarmowych stanowiących pożywkę dla mikroorganizmów tworzących biofilm. Jego pojawienie się w sieci wodociągowej powoduje wzrost barwy, mętności oraz zanieczyszczenie substancjami organicznymi i produktami korozji metali. Rozwój biofilmu może być zahamowany poprzez zastosowanie odpowiedniej dawki dezynfekanta. Przyczyną wtórnego zanieczyszczenia wody w sieci może być także zbyt niska lub wysoka prędkość przepływu wody w systemie powodująca wypłukiwanie osadów. Mniejszy wpływ na wielkość wtórnego zanieczyszczenia ma ciśnienie panujące w sieci [14].

\section{Zdarzenia związane $z$ brakiem dostawy wody do miasta}

\section{Awaria stacji uzdatniania wody lub pompowni wodociagowej}

Warunkiem prawidłowej pracy SUW jest zapewnienie sprawności urządzeń niezbędnych do otrzymania wody o jakości zgodnej z Rozporządzeniem [13] na wyjściu z SUW [19]. Przyczyną niedoboru wody w mieście może być przykładowo awaria jednego $z$ trzech filtrów pospiesznych, w przypadku gdy do prawidłowej pracy systemu wymagana jest praca wszystkich zestawów. Podobnie awaria pompy w pompowni pierwszego i drugiego stopnia może skutkować wstrzymaniem dostawy wody pitnej do miasta. Z tego powodu kluczowe znaczenie dla niezawodności dostawy wody do mieszkańców ma stosowanie rezerwy zimnej lub gorącej zarówno na SUW jak i w pompowniach. Poważne zagrożenie dla ciągłości dostawy wody do miasta stanowi także globalny zanik energii elektrycznej, który jest powodem zatrzymania pracy urządzeń elektrycznych. Eksploatatorzy SZZW powinni kluczowe dla funkcjonowania systemu elementy zaopatrzyć $\mathrm{w}$ agregaty prądotwórcze. Brak dostawy wody do mieszkańców generuje znaczne koszty związane m.in. z koniecznością zakupu wody butelkowanej oraz stanowi dużą uciążliwość.

Priorytetem dla przedsiębiorstw wodociągowych jest zawsze jakość wody. Z tego powodu brak możliwości uzdatnienia odpowiedniej ilości wody zmusza operatorów SUW do ograniczenia lub wstrzymania dostawy wody do miasta.

\section{Awaria glównych przewodów tranzytowych lub magistralnych}

Awaria przewodów tranzytowych lub głównych przewodów magistralnych sieci wodociągowej może pozbawić wody znaczną część mieszkańców. Ze względu na wysokie ciśnienie panujące $w$ takich przewodach, duże średnice, a co za tym idzie znaczną ilość wody wypływającą $\mathrm{z}$ rurociągu w czasie awarii, ich skutki są znaczne i trudne do usunięcia. W odniesieniu do awaryjności przewodów wodociągowych, przez zdarzenie incydentalne należy rozumieć długotrwałe, nagłe i niespodziewane odcięcie znacznej liczby mieszkańców od wody zdatnej do picia. Fakt pozbawienia wody pitnej często wywołuje panikę wśród mieszkańców, która może prowadzić do skrajnych zachowań. 


\section{Sposób zabezpieczenia mieszkańców przed incydentalnym zanieczyszczeniem źródła wody}

\section{System multibariera}

System multibariera jest to skomplikowany system zabezpieczeń mający na celu zabezpieczenie ludności przed spożyciem wody niezdatnej do picia. W skład tego systemu mogą wchodzić bariery takie jak [11]:

- układ późnego ostrzegania,

- układ opóźnionego ostrzegania,

- monitoring wody surowej na ujęciu,

- zamknięcie ujęcia i wykorzystanie wody zgromadzonej w zbiorniku wody surowej,

- uruchomienie alternatywnej technologii uzdatniania,

- wykorzystanie wody zgromadzonej w sieciowych zbiornikach wodociągowych,

- uruchomienie dostawy wody z alternatywnych źródeł,

- układ wczesnego ostrzegania $\mathrm{z}$ wykorzystaniem stacji osłonowo ostrzegawczej.

Dla zapewnienia bezpieczeństwa konsumenta wody kluczowe jest stosowanie stacji osłonowo - ostrzegawczych umożliwiających szybkie wykrycie zanieczyszczenia wody w źródle i uruchomienie działań zapobiegających.

\section{System ostrzegania przed zagrożeniem}

System monitoringu oprócz pozyskiwania aktualnych informacji na temat parametrów jakościowych oraz ilościowych wody w sieci wodociągowej, powinien także zapewniać możliwość jak najszybszego wykrycia zanieczyszczenia wody oraz uwzględniać reprezentatywność wyników badań. Efektywny system wykrywania zanieczyszczeń incydentalnych zabezpiecza mieszkańców przed spożyciem skażonej wody, a tym samym ogranicza ryzyko utraty zdrowia i życia konsumentów. W skład systemu ostrzegania wchodzą [7,19]:

- układ wczesnego ostrzegania - operator otrzymuje wiedzę na temat jakości wody $\mathrm{w}$ źródle $\mathrm{z}$ wyprzedzeniem na podstawie analiz prób wody surowej wykonanej w stacji osłonowo - ostrzegawczej. Układ ten pozwala na podejmowanie racjonalnych decyzji we wczesnym stadium rozwoju sytuacji kryzysowej, np. uruchomienie alternatywnej technologii uzdatniania czy też całkowite zamknięcie ujęcia i korzystanie $\mathrm{z}$ wody zgromadzonej w zbiornikach wodociągowych.

- układ opóźnionego ostrzegania - analizie poddawane są próby wody uzdatnionej na SUW. Po stwierdzeniu skażenia należy bezwzględnie wstrzymać dostawę wody do miasta.

- układ późnego ostrzegania - analizie poddawane są próby wody pobranej w podsystemie dystrybucji wody. W tym przypadku jedyną możliwością ochrony konsumentów przed spożyciem skażonej wody jest ich ostrzeżenie przez radio, telewizję, samochód z systemem nagłaśniającym lub rozwieszenie ulotek.

\section{Uruchomienie alternatywnej technologii uzdatniania}

Operator SUW posiadający informację o rodzaju i skali skażenia, w przypadku gdy główny proces technologiczny nie jest $\mathrm{w}$ stanie usunąć zanieczyszczenia $\mathrm{z}$ wody powinien podjąć decyzję o uruchomieniu alternatywnej technologii uzdatniania, jeżeli występują ku temu możliwości techniczne i ekonomiczne. Do procesów 
Sources of incidental events in collective water supply system

Źródta zdarzeń incydentalnych $w$ systemie zbiorowego zaopatrzenia $w$ wodę

stosowanych w przypadku wykrycia zanieczyszczeń incydentalnych zalicza się: zastosowanie węgla pylistego, zwiększenie dawki koagulanta lub ewentualnie flokulanta oraz zwiększenie dawki dezynfekanta.

\section{Zbiorniki wody czystej i surowej}

Zbiornik wody surowej zabezpiecza przed przedostaniem się skażonej wody do SZZW. Woda zgromadzona w zbiorniku może zostać wykorzystana do zaopatrywania ludności $\mathrm{w}$ wodę zdatną do picia $\mathrm{w}$ przypadku incydentalnego zanieczyszczenia wody $\mathrm{w}$ rzece. Warunkiem sprawnego działania zbiornika jest jego współpraca ze stacją osłonowo - ostrzegawczą wyposażoną w automatyczny analizator wody. Po otrzymaniu informacji o skażeniu, operator może podjąć decyzję o uruchomieniu alternatywnej technologii uzdatniania wody czy też zamknięciu ujęcia. W tym przypadku źródło wody pitnej dla miasta stanowi zbiornik wypełniony wodą pozbawioną substancji niebezpiecznych [5,19].

Zadaniem zbiorników początkowych wody czystej jest gromadzenie wody czystej w celu wyrównywania nierównomierności dobowej rozbioru wody. Zbiorniki te, usytuowane za SUW, przy odpowiedniej pojemności zwiększają bezpieczeństwo konsumentów wody. Posiadając informacje o znacznym wzroście mętności wody w rzece czy tez wystąpieniu incydentalnego skażenia w górze rzeki operator może podjąć decyzję o wcześniejszym napełnieniu zbiornika do maksymalnego możliwego poziomu i korzystaniu ze zgromadzonej wody zdatnej do picia w sytuacji kryzysowej. Przykładowo pojemność zbiornika wody czystej na poziome $\mathrm{Q}_{\text {śr }}$ daje odpowiednim służbom dobę na usunięcie skażenia wody w rzece, bez utraty nominalnej wydajności pompowni drugiego stopnia [4].

Zwiększenie liczby punktów zasilania, np. korzystanie z kilku ujęć wody czy zbiorników sieciowych, podnosi bezpieczeństwo SZZW. W przypadku czasowego wyłączenia ujęcia, zbiorniki sieciowe stabilizują ciśnienie w sieci $[8,16]$.

\section{Podsumowanie}

1) Przynależność systemu zbiorowego zaopatrzenia w wodę do infrastruktury krytycznej wymaga od przedsiębiorstw wodociągowych zapewnienia bezpieczeństwa odbiorcom wody poprzez wdrożenie odpowiedniego systemu zabezpieczeń oraz opracowanie planów reagowania kryzysowego w przypadku wystąpienia zdarzenia incydentalnego.

2) Największe zagrożenie dla zdrowia i życia mieszkańców stanowią zdarzenia incydentalne związane z pogorszeniem jakości wody. Spożycie skażonej wody znajdującej się w podsystemie dystrybucji wody może być powodem masowych zatruć lub zejść śmiertelnych.

3) Sprawny system zabezpieczeń przed incydentalnym zanieczyszczeniem źródła wody dla miasta powinien obejmować system wczesnego, późnego oraz opóźnionego ostrzegania, wykorzystanie wody zgromadzonej w zbiorniku wody surowej oraz zbiornikach sieciowych wody czystej, uruchomienie alternatywnych źródeł wody oraz alternatywnej technologii uzdatniania.

4) Przeprowadzona analiza zdarzeń incydentalnych może stanowić punkt wyjścia do oceny bezpieczeństwa SZZW. 


\section{Literatura}

[1] Guzowska I.: Higiena zbiorników wodociągowych, Ochrona Środowiska, $1(76) / 2000,11-14$.

[2] Lipińska E.: Powódź 2010 - przyczyny i skutki, Wojewódzki Inspektorat Ochrony Środowiska, $38-42$.

[3] Mioduszewski W.: Zjawiska ekstremalne w przyrodzie - susze i powodzie, Współczesne Problemy Kształtowania i Ochrony Środowiska, Monografie nr 3p, 2012 „Wybrane problemy ochrony mokradeł”, 57 - 74.

[4] Olearczyk - Siwik B.: Problem nadmiernej mętności wody surowej na przykładzie zbiornika Czaniec, Prace Naukowe GIG, Górnictwo i Środowisko, 2/2010, $63-74$.

[5] Pawełek J.: Zabezpieczenie rzecznych ujęć komunalnych $\mathrm{w}$ stanach nadmiernych mętności wody, Międzynarodowa Konferencja Naukowo Techniczna „Zaopatrzenie w wodę miast i wsi”, Poznań 1996, 3 - 17.

[6] Pawula A.: Zagrożenia i skutki promieniotwórczego skażenia wody, Ochrona Środowiska, 3(58)/1995, 23 - 28.

[7] Pietrucha - Urbanik K., Rak J., Tchórzewska - Cieślak B.: Safety analysis of water supply systems including protection barriers, Journal of Polish Safety and Reliability Association, Summer Safety and Reliability Seminars, Volume 3, Number 2, 2013, $241-248$.

[8] Rak J.: Metoda szacowania ryzyka zagrożenia systemu zaopatrzenia w wodę, Ochrona Środowiska, 2/2003, 33 - 36.

[9] Rak J. i inni: Metody oceny niezawodności i bezpieczeństwa dostawy wody do odbiorców, Oficyna wydawnicza Politechniki Rzeszowskiej, Rzeszów $2013,32-37$.

[10] Rak J., Kucharski B.: Zdarzenia nadzwyczajne - poważne awarie. Gaz, woda i technika sanitarna, 10/2003, 350-352.

[11] Rak J., Tchórzewska - Cieślak B.: Metody analizy i oceny ryzyka w systemie zaopatrzenia w wodę, Oficyna wydawnicza Politechniki Rzeszowskiej, Rzeszów 2005, 27 - 55.

[12] Rak J., Zamorska J. Zagrożenia terrorystyczne $\mathrm{z}$ użyciem środków chemicznych i biologicznych, Czasopismo Techniczne, Środowisko, Wydawnictwo Politechniki Krakowskiej im. Tadeusza Kościuszki, R. 101, z. 8-Ś, $165-172$.

[13] Rozporządzenie Ministra Zdrowia z dnia 29 marca 2007 roku w sprawie jakości wody przeznaczonej do spożycia przez ludzi wraz ze zmianami z 20 kwietnia 2010 roku.

[14] Świderska - Broź M., Wolska M.: Główne przyczyny wtórnego zanieczyszczenia wody w systemie dystrybucji, Ochrona Środowiska, 4/2006, $31-34$.

[15] Tchórzewska - Cieślak B.: Metody analizy i oceny ryzyka awarii podsystemu dystrybucji wody, Oficyna Wydawnicza Politechniki Rzeszowskiej, Rzeszów 2011.

[16] Tchórzewska - Cieślak B., Piegdoń I., Szpak D.: Water supply of urban agglomeration in crisis situation, Journal of Polish Safety and Reliability Association, Summer Safety and Reliability Seminars, Volume 5, Number 1, 2014, $143-154$. 
Sources of incidental events in collective water supply system

Źródła zdarzeń incydentalnych $w$ systemie zbiorowego zaopatrzenia $w$ wode

[17] Ustawa z dnia 26 kwietnia 2007 r. o zarządzaniu kryzysowym (Dz. U. z 2007 r. Nr 89, poz. 590) oraz zmiana z 2010 r., Dz.U.240 poz. 1600.

[18] Ustawa z dnia 27 kwietnia 2001 roku Prawo ochrony środowiska, Dz.U. 2001 nr 62 poz. 627 wraz z późniejszymi zmianami.

[19] Wieczysty A., Rak J.: Sposoby ochrony systemu zaopatrzenia w wodę miasta przed incydentalnymi zanieczyszczeniami, PZIiTS, Oddział w Krakowie, VII Ogólnopolskie Seminarium Naukowo - Techniczne Ochrona Jakości i Zasobów Wód „Zasady racjonalnej gospodarki wodą”, Zakopane 1996, $147-158$.

[20] Żuber M.: Groźba użycia broni masowego rażenia w atakach terrorystycznych, Katastrofy naturalne i cywilizacyjne, Zagrożenia i reagowanie kryzysowe, Wrocław 2006.

[21] Cyberterroryzm, msz.gov.pl, dostęp: 13.10.2014, <http://www.msz.gov.pl

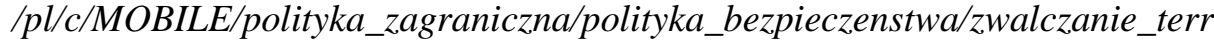
oryzmu_miedzynarodowego/zagrozenie_terrorystyczne_w_polsce_i_regioniel cyberterroryzm/ $>$.

[22] Występowanie zdarzeń o znamionach poważnej awarii, gios.gov.pl, dostęp: 10.10.2014, <http://www.gios.gov.pl/artykuly/podkategoria/16/Wystepowanie -zdarzen-o-znamionach-powaznej-awarii>.

[23] Zagrożenie terrorystyczne w Polsce i regionie, msz.gov.pl, dostęp: 13.10.2014, <http://www.msz.gov.pl/pl/polityka_zagraniczna/polityka_ bezpieczenstwa/zwalczanie_terroryzmu_miedzynarodowego/zagrozenie_ terrorystyczne_w_polsce_i_regioniel>.

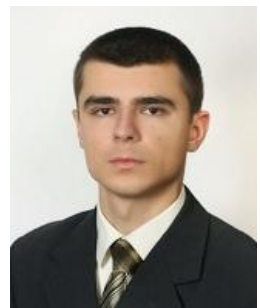

Mgr inz. Dawid Szpak w roku 2013 ukończyt studia na Wydziale Budownictwa i Inżynierii Środowiska Politechniki Rzeszowskiej. Pracuje na stanowisku asystenta $w$ Katedrze Zaopatrzenia w Wodę i Odprowadzania Ścieków Politechniki Rzeszowskiej. Zainteresowania naukowe: niezawodność $w$ systemach zbiorowego zaopatrzenia $w$ wode, zdarzenia incydentalne $w$ systemach zbiorowego zaopatrzenia $w$ wodę.

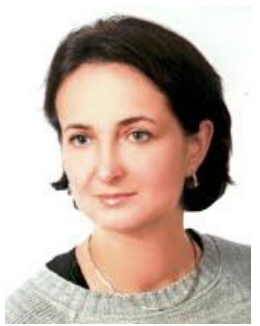

Dr hab. inż. Barbara Tchórzewska - Cieślak, prof. PRz pracuje na stanowisku profesora nadzwyczajnego $w$ Katedrze Zaopatrzenia $w$ Wodę $i$ Odprowadzania Ścieków Politechniki Rzeszowskiej. Zainteresowania naukowe: eksploatacja systemów zbiorowego zaopatrzenia $w$ wodę, niezawodność $i$ bezpieczeństwo systemów inżynierskich, niekonwencjonalne metody analizy i oceny ryzyka. 